\title{
Integrated Circuit Device
}

National Cancer Institute

\section{Source}

National Cancer Institute. Integrated Circuit Device. NCI Thesaurus. Code C49994.

A device that uses only integrated circuits. 